\section{Optimising load to optimise outcomes}

\author{
Philip Glasgow
}

\section{OPTIMISING OUR LOADING}

The human body is attuned to respond to various forms of mechanical loading and that this is perhaps the primary tool in the repertoire of sports medicine professionals. If exercise is the intervention of choice for a range of conditions, we must appreciate the mechanisms that underpin adaptation so we can refine our prescription and better benefit patients. The current issue of BJSM highlights a range of strategies that can be used to better monitor, manipulate and apply load in a range of contexts.

\section{WHAT MECHANISMS ARE WE TRYING TO STIMULATE?}

Mechanical loading can take many different forms and may involve the manipulation of loading variables to stimulate specific metabolic, neural and morphological changes. The manipulation of training variables, whether in healthy or injured athletes, can have a profound effect on both the rate and quality of recovery or the incidence of injury.

Correspondence to Professor Philip Glasgow, School of Sport, Ulster University, Shore Road, Newtownabbey BT37 0QB, UK; philglasgow@hotmail.com is also highlighted (see page 992). neuromuscular training using a mobile app are other practical gems in this issue.

\section{OPTIMAL LOADING IN SPORT: BELFAST} 2017

The role of effective periodisation and exercise progression has been a central tenet of sports training for many years. In a fascinating editorial, Johann Windt and colleagues (see page 994) discuss of how spikes in workload may cause injuries and how we clinicians can identify key factors to aid exercise prescription. We are also reminded that the decisions we make regarding training load can have implications beyond the immediate session. The influence of training volume and soft tissue injury in rugby union is presented by Orr et al (see page 1013), while the never-ending search for the perfect acute:chronic workload ratio and its relationship to injury definition

Different exercises can have different effects of specific tissues. Practical considerations for selection of hamstring exercises that may help direct our decisions related to specific morphological changes are presented (see page 1022). Responses to load are of course not limited to solely morphological changes with many of the interventions we prescribe also having a significant influence on the nervous system. Motor control training for low back pain and strategies to evaluate the effects of
One other great way to enhance your practice in prescription of loading is to come to Belfast on 6th and 7th October. This year Physios in Sport (UK) will host the 2nd World Congress of Sports Physical Therapy where the theme will be Optimal Loading in Sport. The Congress program features a fantastic lineup of speakers who will consider ways for us to use the best evidence to make better clinical decisions regarding the use of mechanical loading to manage injuries of different biological tissue types. We look forward to welcoming you to Belfast in October. For more information or to book your place at the Congress visit: www.physiosinsport.org or follow us on Twitter:@opload2017.

Competing interests None declared.

Provenance and peer review Commissioned; internally peer reviewed.

(c) Article author(s) (or their employer(s) unless otherwise stated in the text of the article) 2017. All rights reserved. No commercial use is permitted unless otherwise expressly granted.

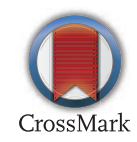

To cite Glasgow P. Br J Sports Med 2017;51:985.

Br J Sports Med 2017:51:985.

doi:10.1136/bjsports-2017-098048 